\title{
Large Emissions of Low-Volatility Siloxanes During Residential Oven Use
}

Erin F. Katz ${ }^{1,2 *}$, David M. Lunderberg ${ }^{1,2}$, Wyatt L. Brown ${ }^{3}$, Douglas A. Day ${ }^{3}$, Jose L. Jimenez ${ }^{3}$, William W Nazaroff ${ }^{4}$, Allen H. Goldstein ${ }^{2,4^{*}}$, Peter F. DeCarlo ${ }^{5 *}$

1. Department of Chemistry, University of California, Berkeley, California 94720, United States

2. Department of Environmental Science, Policy, and Management, University of California, Berkeley, California 94720, United States

3. Department of Chemistry and CIRES, University of Colorado, Boulder, Colorado 80309, United States

4. Department of Civil and Environmental Engineering, University of California, Berkeley, California 94720, United States

5. Department of Environmental Health and Engineering, Johns Hopkins University, Baltimore, Maryland 21211, United States

* Indicates corresponding authors

Supplemental Information 

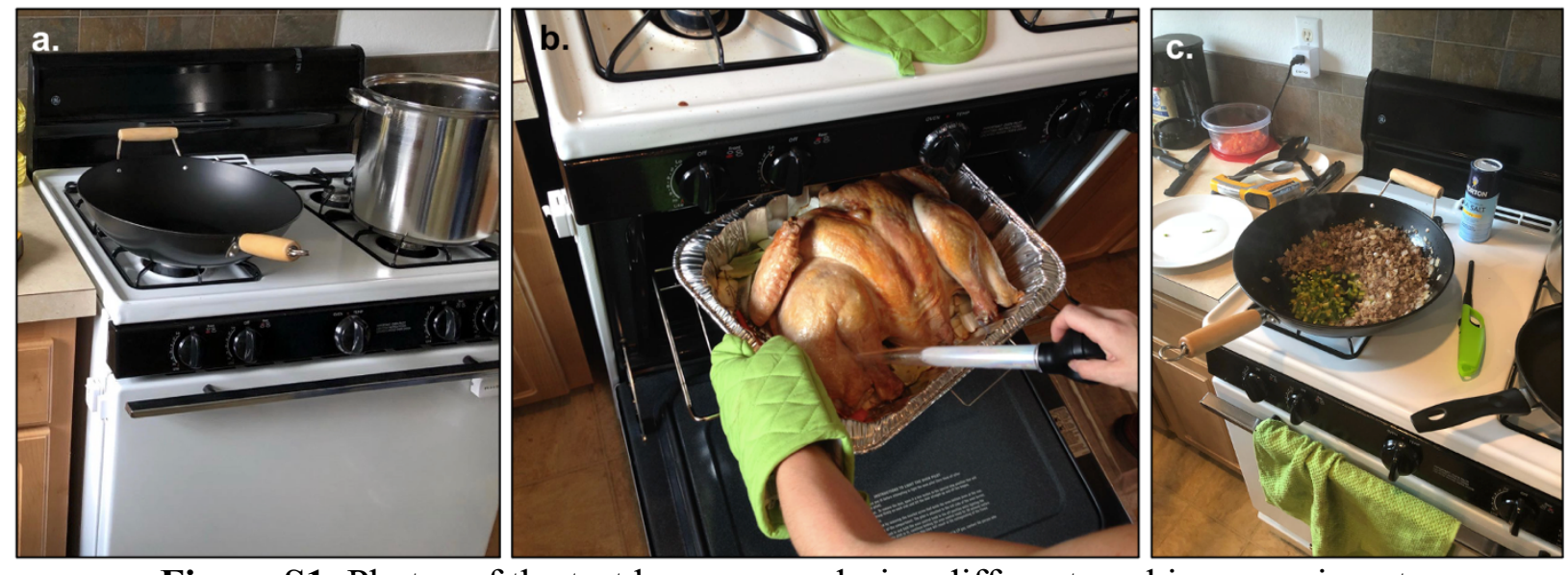

Figure S1: Photos of the test house oven during different cooking experiments 


\section{Instrument Details}

Instruments described below, which provided continuous in-situ measurements, were situated in air-conditioned trailers adjacent to the test house and sampled via insulated tubing from the kitchen.

The HR-AMS analyzes the composition of non-refractory particles with vacuum aerodynamic diameters between 35 and $1500 \mathrm{~nm} .{ }^{1}$ Non-refractory particle species sampled by the instrument are vaporized at $600{ }^{\circ} \mathrm{C}$, ionized in the gas phase via $70-\mathrm{eV}$ electron ionization (EI), and pulsed through a time-of-flight mass spectrometer. Size distributions are calculated as a function of the particles' time of flight through the particle time-of-flight (PToF) region of the instrument. Species mass concentrations are calculated using a scaling factor to the ionization efficiency (IE) of the primary calibrant, nitrate, called the relative ionization efficiency (RIE). The HR-AMS at HOMEChem analyzed masses up to $m / z 360$ and sampled indoor and outdoor air through copper and then stainless-steel tubing (3/4" and $1 / 4$ " outer diameter). The siloxane ions detected by the HRAMS are shown in Figure S2 and Table S1, and are similar to fragments detected by Timko et al. 2 in AMS data from silicone tubing contamination. At HOMEChem, the $I E$ was calculated using size-select ammonium nitrate, and PToF was calibrated using polystyrene latex spheres and sizeselect ammonium nitrate. The summed signal of the siloxane ions was converted to a mass concentration using the standard relative ionization efficiency (RIE) applied to organics (1.4). A collection efficiency $(C E)$ of 1.0 was assumed for siloxanes because they were internally mixed with the typically liquid organic aerosol emitted during cooking (see Results), which have a $C E$ of 1.0. ${ }^{3}$ The calibration factors applied resulted in good agreement with the co-located instruments. Siloxane size distributions were derived from unit mass resolved siloxane ions above $\mathrm{m} / \mathrm{z} 147 \mathrm{(m} / \mathrm{z}$ $207,221,281$, etc.) to minimize potential interference from other organic species. Further details on the instrument setup and calibrations, such as inlet losses, are presented in Katz et al. ${ }^{4}$

Without commercially available genuine standards to calibrate for the siloxanes of interest in airborne particles, we use the RIE of organic aerosols to estimate siloxane concentrations with the HR-AMS. Despite not using a siloxane-specific calibration factor, there is good agreement between the HR-AMS and the SV-TAG (Figure S3). The $2 \sigma$ uncertainty for siloxane concentration is estimated at $39 \%$, with $20 \%$ uncertainty assumed for the $R I E, 30 \%$ uncertainty for the $C E, 15 \%$ uncertainty for the nitrate ionization efficiency, and 5\% uncertainty for the instrument flow rate. ${ }^{5}$ The HR-AMS may be measuring a fraction of the siloxane fragments owing to the limited mass range of the instrument (the HR-AMS analyzed up to $m / z$ 360), but good agreement with co-located instruments was observed using $R I E=1.4$. However, the actual $R I E$ may be higher if mass fragments above $m / z 360$ were prominent features of the siloxane mass spectrum in the HR-AMS. The SV-TAG, which analyzed up to $m / z 549$, showed signal above $\mathrm{m} / z 360$ for the low-volatility cyclic siloxanes. SV-TAG mass spectra of D17, D18, and D19 resulted in $12 \%, 20 \%$, and $8 \%$ of the total signal above $\mathrm{m} / \mathrm{z} 360$, respectively. However, because of the combined vaporization and ionization in the HR-AMS, it is possible that fragmentation would be more extensive than in standard EI mass spectrometry.

SV-TAG ${ }^{6-8}$ simultaneously sampled indoor air hourly in two separate collection cells (with 20minute sample collection followed by analysis). Sample air was drawn to the SV-TAG via stainless steel tubing (5/8" outer diameter). A cyclone selected particles smaller than $2.5 \mu \mathrm{m}$ for both cells, and a denuder removed organic gases from the flow leading to the second cell. Analytes were thermally desorbed and characterized via coupled gas chromatography and 70-eV EI mass spectrometry. The dual sampling cells allowed for simultaneous characterization of gas plus particle concentrations and particle-only concentrations (i.e., from denuded air). The D10 through 
D20 siloxanes were detected by the SV-TAG, with D10 through D18 quantified using the nearest alkane in retention time as a calibration surrogate. ${ }^{8}$ The estimated uncertainty is $15 \%{ }^{7}$ Particleonly concentrations were calculated for D13 through D18.

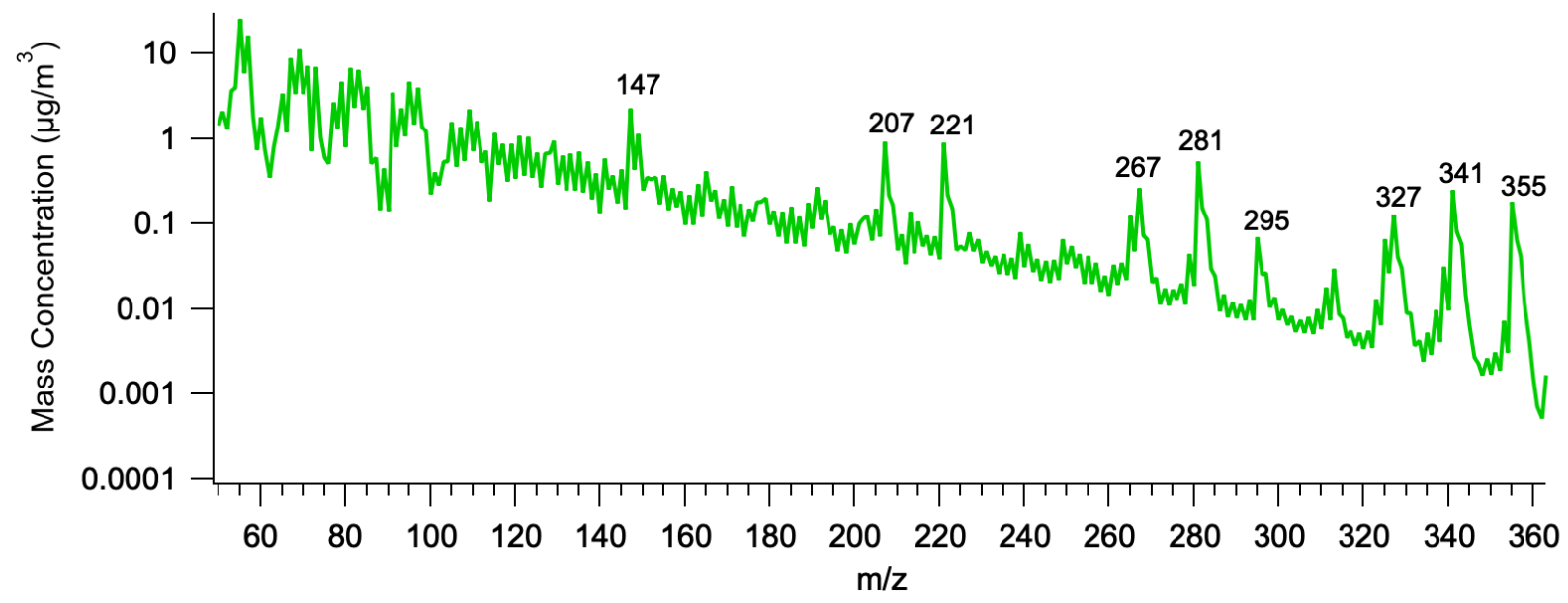

Figure S2: Unit mass resolution organic aerosol mass spectrum for $m / z>50$ measured by the AMS on a log scale. The data shown are an average from both Thanksiving experiments. The labeled ions are characteristic of siloxanes.

Table S1: Siloxane ions $\left(\mathrm{C}_{w} \mathrm{H}_{x} \mathrm{O}_{y} \mathrm{Si}_{z}{ }^{+}\right)$quantified by the HR-AMS. ${ }^{a}$

\begin{tabular}{|c|c|c|}
\hline Formula & Nominal Mass & Exact Mass \\
\hline $\mathrm{C}_{2} \mathrm{H}_{7} \mathrm{Si}^{+}$ & 59 & 59.0317 \\
\hline $\mathrm{C}_{3} \mathrm{H}_{9} \mathrm{Si}^{+}$ & 73 & 73.0473 \\
\hline $\mathrm{C}_{3} \mathrm{H}_{9} \mathrm{O}_{2} \mathrm{Si}_{2}{ }^{+}$ & 133 & 133.014 \\
\hline $\mathrm{C}_{5} \mathrm{H}_{15} \mathrm{OSSi}_{2}{ }^{+}$ & 147 & 147.066 \\
\hline $\mathrm{C}_{5} \mathrm{H}_{15} \mathrm{O}_{3} \mathrm{Si}_{3}{ }^{+}$ & 207 & 207.033 \\
\hline $\mathrm{C}_{7} \mathrm{H}_{21} \mathrm{O}_{2} \mathrm{Si}_{3}{ }^{+}$ & 221 & 221.085 \\
\hline $\mathrm{C}_{6} \mathrm{H}_{17} \mathrm{O}_{4} \mathrm{Si}_{4}{ }^{+}$ & 265 & 265.020 \\
\hline $\mathrm{C}_{5} \mathrm{H}_{15} \mathrm{O}_{5} \mathrm{Si}_{4}{ }^{+}$ & 267 & 267.000 \\
\hline $\mathrm{C}_{8} \mathrm{H}_{23} \mathrm{O}_{3} \mathrm{Si}_{4}{ }^{+}$ & 279 & 279.072 \\
\hline $\mathrm{C}_{7} \mathrm{H}_{21} \mathrm{O}_{4} \mathrm{Si}_{4}{ }^{+}$ & 281 & 281.052 \\
\hline $\mathrm{C}_{9} \mathrm{H}_{27} \mathrm{O}_{3} \mathrm{Si}_{4}{ }^{+}$ & 295 & 295.104 \\
\hline $\mathrm{C}_{6} \mathrm{H}_{17} \mathrm{O}_{6} \mathrm{Si}_{5}{ }^{+}$ & 325 & 324.987 \\
\hline $\mathrm{C}_{5} \mathrm{H}_{15} \mathrm{O}_{7} \mathrm{Si}_{5}{ }^{+}$ & 327 & 326.966 \\
\hline $\mathrm{C}_{8} \mathrm{H}_{23} \mathrm{O}_{5} \mathrm{Si}_{5}{ }^{+}$ & 339 & 339.039 \\
\hline $\mathrm{C}_{7} \mathrm{H}_{21} \mathrm{O}_{6} \mathrm{Si}_{5}{ }^{+}$ & 341 & 341.018 \\
\hline $\mathrm{C}_{9} \mathrm{H}_{27} \mathrm{O}_{5} \mathrm{Si}_{5}{ }^{+}$ & 355 & 355.070 \\
\hline
\end{tabular}

${ }^{a}$ Signal from the ions listed and their isotopes were summed and converted to the reported mass concentrations in the main article using an RIE of 1.4 and CE of 1.0. 


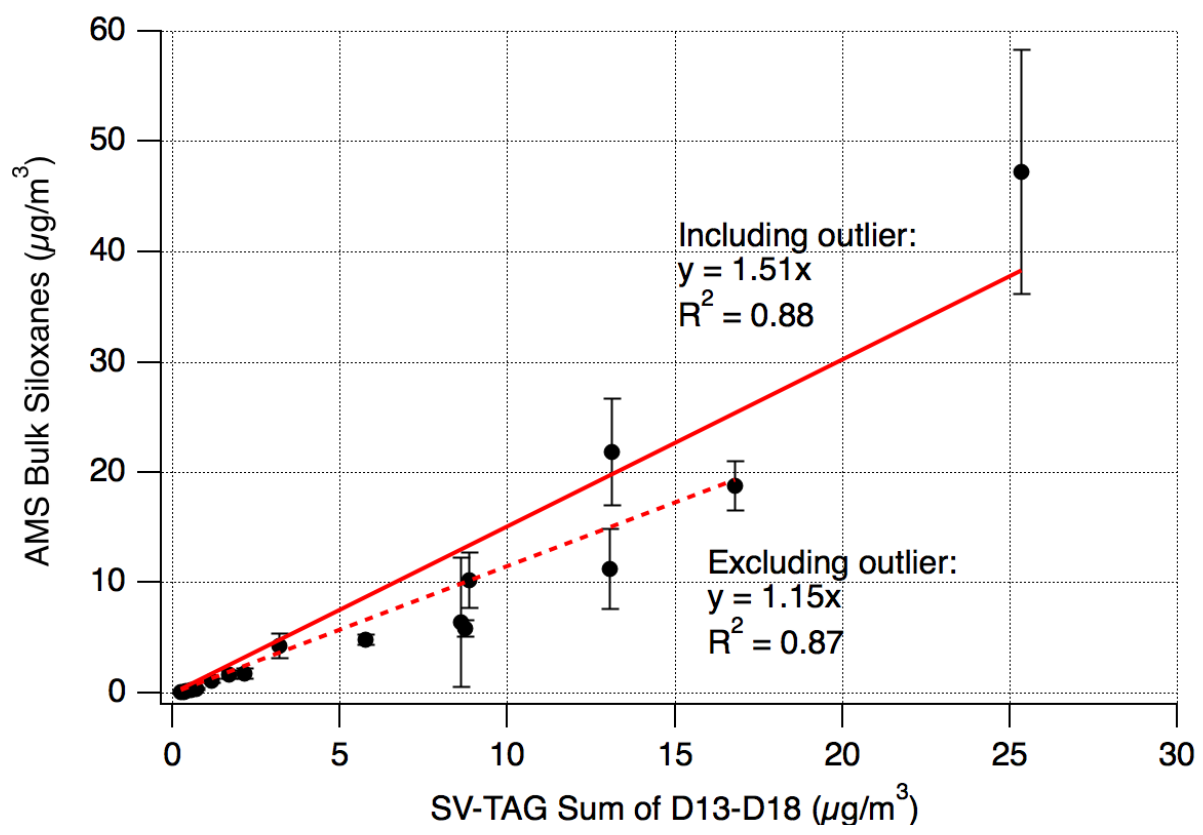

Figure S3: Comparison between HR-AMS bulk siloxane concentration and SV-TAG sum of particle only signal for D13-D18. Orthogonal distance regression fits through the origin are displayed. The highest point is believed to be an outlier, as it includes contributions from other siloxanes in addition to D13-D18 for the AMS measurement. Thus, two fits are shown: including and excluding the outlier. 

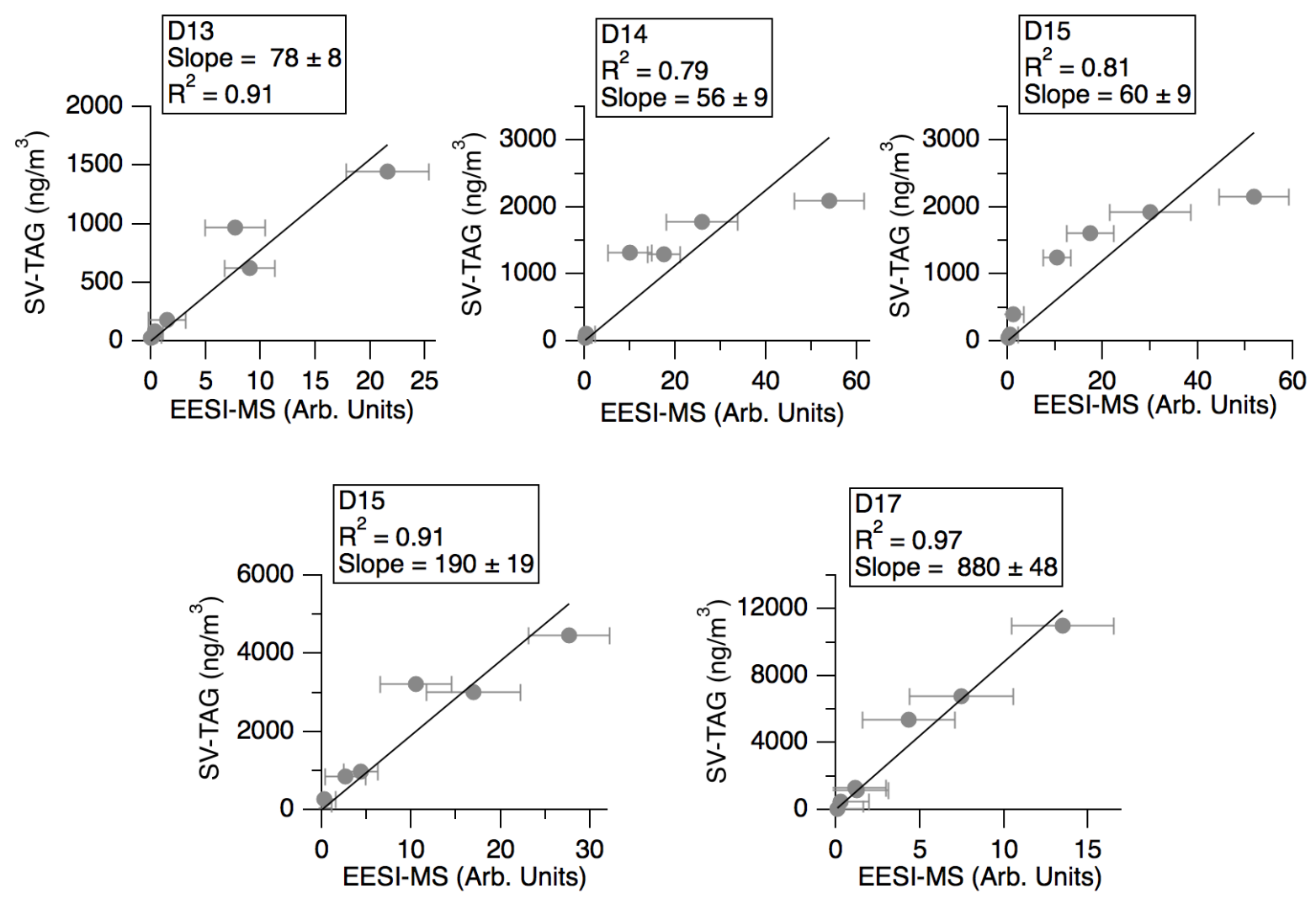

Figure S4: Calibration curves used to convert EESI-MS arbitrary units to $\mathrm{ng} / \mathrm{m}^{3}$ and then $\mu \mathrm{g} / \mathrm{m}^{3}$. SV-TAG data are plotted versus EESI-MS data averaged over the SV-TAG collection period. Error bars represent the EESI-MS standard deviation over the averaging period. The data were fit using orthogonal distance regression through $y=0$. Slope and $R^{2}$ are displayed for each siloxane detected by the EESI-MS. 


\section{D17 Condensation Loss Rates to Indoor Particles and Surfaces}

The loss rate coefficient for condensation to airborne particles, $L_{p}$, was calculated using the following equation. ${ }^{9}$

$$
L_{p}=\int_{-\infty}^{\infty} 2 \pi D d_{p}\left[\frac{1+\mathrm{Kn}}{1+1.71 \mathrm{Kn}+1.333 \mathrm{Kn}^{2}}\right] \frac{d N}{d\left(\log d_{p}\right)} d\left(\log d_{p}\right)
$$

$D$ is diffusivity of D17 in air $\left(D=0.02 \mathrm{~cm}^{2} / \mathrm{s}\right)$. $D$ was estimated using the Stokes-Einstein relation with the Cunningham slip correction factor for a particle with volume equal to the effective volume of a D17 molecule given its molecular weight $(1258 \mathrm{~g} / \mathrm{mol})$ and density of PDMS $\left(0.965 \mathrm{~g} / \mathrm{cm}^{3}\right)$. $d_{p}$ is the particle physical diameter, and $\mathrm{Kn}$ is the Knudsen number $\left(2 \lambda / d_{p}, \lambda=\right.$ mean free path of SVOC in air $=0.065 \mu \mathrm{m}) . \mathrm{d} N / \mathrm{d}\left(\log d_{p}\right)$ and corresponding $d_{p}$ were averaged over the period of peak siloxane concentration during HOMEChem Thanksgiving 1 (SMPS measurement). $L_{p}$ was $0.13 \mathrm{~s}^{-1}$ or $450 \mathrm{~h}^{-1}$. The loss rate to indoor surfaces, $L_{s}$, was calculated using the following equation.

$$
L_{p}=v_{d} \times S / V
$$

Here, $v_{d}$ is the deposition velocity and is proportional to $D^{2 / 3} \cdot{ }^{10}$ The $v_{d}$ value published by Wang et al. ${ }^{11}$ for HOMEChem experimental data was $1 \mathrm{~m} / \mathrm{h}$. We also refer to Wang et al. ${ }^{11}$ for the $S / V$, or indoor surface area to volume ratio $\left(S / V=3 \mathrm{~m}^{-1}\right.$, a typical value). $L_{p}$ was $\sim 3 \mathrm{~h}^{-1}$ using these values.

Although the uncertainty in the rate constants presented may be high, the assessed fate is not sensitive to these uncertainties due to the large difference between the loss to particles and loss to surfaces $\left(450 \mathrm{~h}^{-1}\right.$ versus $\left.3 \mathrm{~h}^{-1}\right)$. Even if the uncertainties were as high as $\pm 50 \%$, the ultimate outcome of the calculation ( $99 \%$ of molecular D17 lost to airborne particles) would not be affected. 
Table S2: Concentrations of particle-only cyclic siloxanes during each Thanksgiving experiment measured by $S V$-TAG. Limits of detection vary by time-of-day due to other coeluting analytes and are typically on the order of 10-100 $\mathrm{ng} \mathrm{m}^{-3}$.

\begin{tabular}{|c|c|c|c|c|c|c|c|c|c|}
\hline \multicolumn{10}{|c|}{$\begin{array}{c}\text { Thanksgiving } 1 \text { (June } 18,2018) \\
\text { Particle-only cyclic siloxane concentrations }\left(\mathrm{ng} / \mathrm{m}^{3}\right)\end{array}$} \\
\hline Time (hh:mm) & D10 & D11 & D12 & D13 & D14 & D15 & D16 & D17 & D18 \\
\hline $9: 05-9: 25$ & 8 & 9 & 94 & 22 & 22 & 18 & 23 & 39 & 21 \\
\hline $10: 05-10: 25$ & 11 & 14 & 41 & 80 & 70 & 46 & 42 & 58 & 27 \\
\hline $11: 05-11: 25$ & 11 & 13 & 111 & 600 & 1300 & 1200 & 1000 & 1100 & 300 \\
\hline $12: 05-12: 25$ & 5 & 9 & 17 & 58 & 400 & 400 & 600 & 600 & 133 \\
\hline $13: 05-13: 25$ & - & - & - & - & - & - & & - & \\
\hline $14: 05-14: 25$ & 24 & 25 & 162 & 1000 & 1800 & 1900 & 3000 & 6800 & 2100 \\
\hline $15: 05-15: 25$ & 8 & 19 & 300 & 1400 & 2000 & 2100 & 4500 & 11000 & 3800 \\
\hline $16: 05-16: 25$ & 8 & 19 & 144 & 181 & 1300 & 1600 & 3200 & 5400 & 1200 \\
\hline $17: 05-17: 25$ & 11 & 10 & 33 & 37 & 112 & 400 & 800 & 1300 & 400 \\
\hline $18: 05-18: 25$ & 7 & 11 & 14 & 29 & 50 & 91 & 300 & 500 & 183 \\
\hline 19:05-19:25 & 11 & 11 & 12 & 24 & 36 & 35 & 115 & 232 & 79 \\
\hline Average & 10 & 14 & 92 & 350 & 700 & 800 & 1400 & 2700 & 800 \\
\hline \multicolumn{10}{|c|}{$\begin{array}{c}\text { Thanksgiving } 2 \text { (June } 27,2018) \\
\text { Particle-only cyclic siloxane concentrations }\left(\mathrm{ng} / \mathrm{m}^{3}\right)\end{array}$} \\
\hline Time (hh:mm) & D10 & D11 & D12 & D13 & D14 & D15 & D16 & D17 & D18 \\
\hline $9: 05-9: 25$ & 14 & 14 & 0 & 29 & 29 & 19 & 34 & 0 & 0 \\
\hline $10: 05-10: 25$ & 18 & 15 & 25 & 57 & 61 & 34 & 37 & 80 & 0 \\
\hline $11: 05-11: 25$ & 15 & 14 & 43 & 500 & 1700 & 1400 & 2100 & 2500 & 400 \\
\hline $12: 05-12: 25$ & - & - & - & - & - & - & - & - & - \\
\hline $13: 05-13: 25$ & 16 & 37 & 400 & 1200 & 1700 & 1100 & 1800 & 2000 & 300 \\
\hline $14: 05-14: 25$ & 18 & 17 & 0 & 700 & 1800 & 1600 & 3000 & 3200 & 400 \\
\hline $15: 05-15: 25$ & 16 & 15 & 72 & 500 & 1700 & 1700 & 4000 & 4600 & 500 \\
\hline $16: 05-16: 25$ & 18 & 14 & 15 & 52 & 400 & 1000 & 3000 & 4000 & 300 \\
\hline $17: 05-17: 25$ & 14 & 15 & 23 & 44 & 59 & 84 & 600 & 800 & 101 \\
\hline $18: 05-18: 25$ & 15 & 15 & 21 & 29 & 46 & 39 & 163 & 300 & 103 \\
\hline 19:05-19:25 & 16 & 17 & 22 & 0 & 40 & 36 & 76 & 119 & 66 \\
\hline Average & 16 & 17 & 74 & 300 & 700 & 700 & 1500 & 1800 & 214 \\
\hline
\end{tabular}




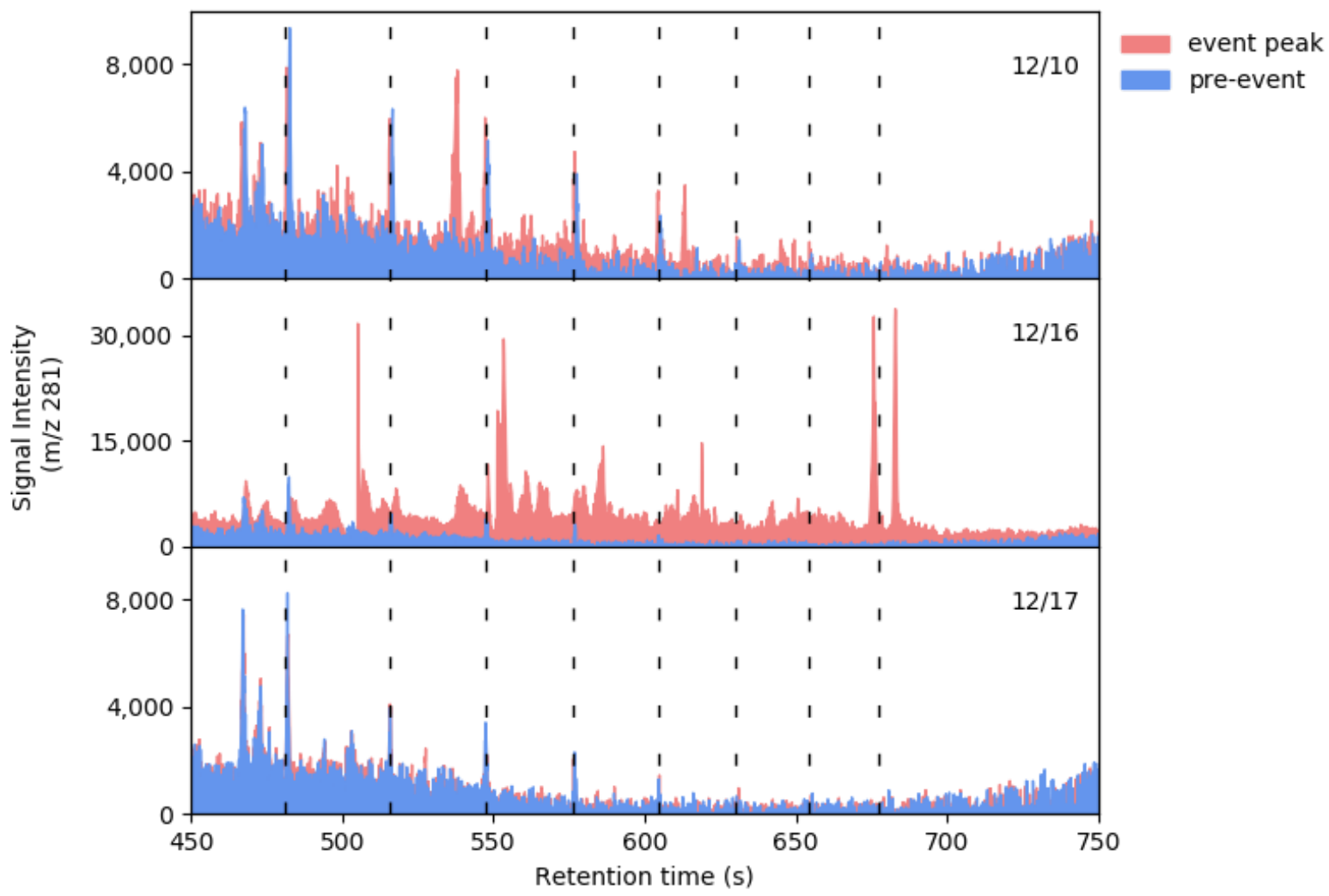

Figure S5: SV-TAG chromatograms for $\mathrm{m} / z$ 281, a characteristic siloxane ion fragment, during and prior to three oven use events at $\mathrm{H} 2$. Vertical lines correspond to the expected retention times of D11 to D18. 12/10: chicken, potatoes, root vegetables, onions prepared 4:30 pm to 4:55 pm. 12/16: cauliflower and broccoli. 12/17: wedding cookies prepared 9:35 am to 10:27 am. 


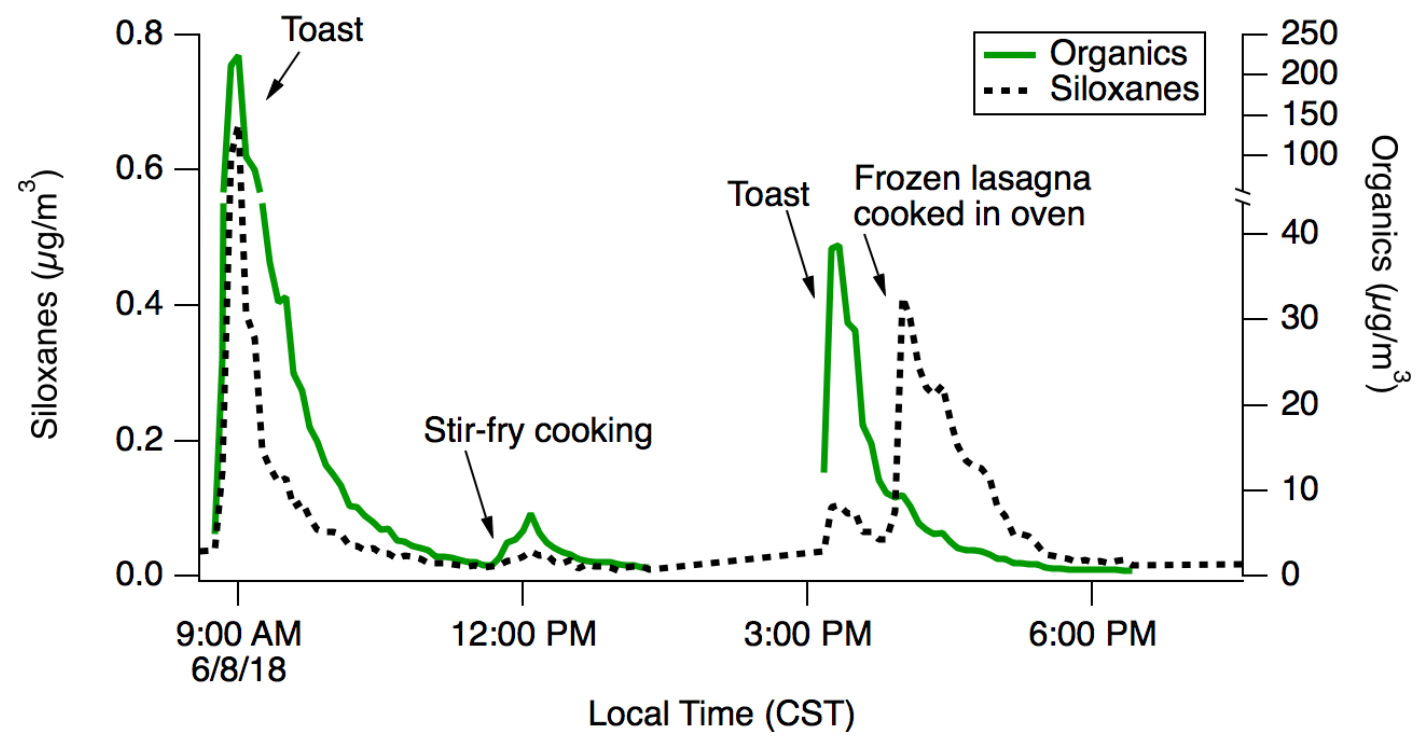

Figure S6: Time series of bulk siloxanes and organics measured by HR-AMS during the HOMEChem June 8 "Layered Day" experiment. During "toast" events only a toaster oven was used to toast bread. During "stir-fry cooking," a non-stick wok was used on the gas stove. The frozen lasagna was cooked in the oven using the baking tray provided in the package. 


\section{References}

1. Hu, W.; Campuzano-Jost, P.; Day, D. A.; Croteau, P.; Canagaratna, M. R.; Jayne, J. T.; Worsnop, D. R.; Jimenez, J. L., Evaluation of the new capture vapourizer for aerosol mass spectrometers (AMS) through laboratory studies of inorganic species. Atmos. Meas. Tech. 2017, $10(8), 2897-2921$.

2. Timko, M. T.; Yu, Z.; Kroll, J.; Jayne, J. T.; Worsnop, D. R.; Miake-Lye, R. C.; Onasch, T. B.; Liscinsky, D.; Kirchstetter, T. W.; Destaillats, H.; Holder, A. L.; Smith, J. D.; Wilson, K. R., Sampling Artifacts from Conductive Silicone Tubing. Aerosol Sci. Technol. 2009, 43 (9), 855865.

3. Matthew, B. M.; Middlebrook, A. M.; Onasch, T. B., Collection efficiencies in an Aerodyne aerosol mass spectrometer as a function of particle phase for laboratory generated aerosols. Aerosol Sci. Technol. 2008, 42, 884-898.

4. Katz, E. F.; Guo, H.; Campuzano-Jost, P.; Day, D. A.; Brown, W. L.; Boedicker, E.; Pothier, M.; Lunderberg, D. M.; Patel, S.; Patel, K.; Hayes, P. L.; Avery, A.; Ruiz, L. H.; Goldstein, A. H.; Vance, M. E.; Farmer, D. K.; Jimenez, J. L.; DeCarlo, P. F., Quantification of cooking organic aerosol in the indoor environment using Aerodyne aerosol mass spectrometers. Aerosol Sci. Technol. 2021.

5. Bahreini, R.; Ervens, B.; Middlebrook, A. M.; Warneke, C.; Gouw, J. A. d.; DeCarlo, P. F.; Jimenez, J. L.; Brock, C. A.; Neuman, J. A.; Ryerson, T. B.; Stark, H.; Atlas, E.; Brioude, J.; Fried, A.; Holloway, J. S.; Peischl, J.; Richter, D.; Walega, J.; Weibring, P.; Wollny, A. G.; Fehsenfeld, F. C., Organic aerosol formation in urban and industrial plumes near Houston and Dallas, TX. J. Geophys. Res. 2009, 114.

6. Zhao, Y.; Kreisberg, N. M.; Worton, D. R.; Teng, A. P.; Hering, S. V.; Goldstein, A. H., Development of an In Situ Thermal Desorption Gas Chromatography Instrument for Quantifying Atmospheric Semi-Volatile Organic Compounds. Aerosol Sci. Technol. 2013, 47 (3), 258-266.

7. Isaacman, G.; Kreisberg, N. M.; Yee, L. D.; Worton, D. R.; Chan, A. W. H.; Moss, J. A.; Hering, S. V.; Goldstein, A. H., Online derivatization for hourly measurements of gas- and particle-phase semi-volatile oxygenated organic compounds by thermal desorption aerosol gas chromatography (SV-TAG). Atmos. Meas. Tech. 2014, 7 (12), 4417-4429.

8. $\quad$ Lunderberg, D. M.; Kristensen, K.; Tian, Y.; Arata, C.; Misztal, P. K.; Liu, Y.; Kreisberg, N.; Katz, E. F.; DeCarlo, P. F.; Patel, S.; Vance, M. E.; Nazaroff, W. W.; Goldstein, A. H., Surface Emissions Modulate Indoor SVOC Concentrations through Volatility-Dependent Partitioning. Environ. Sci. Technol. 2020, 54 (11), 6751-6760.

9. Seinfeld, J. H.; Pandis, S. N., Atmospheric Chemistry and Physics: From Air Pollution to Climate Change. 3 ed.; John Wiley \& Sons, Inc: Hoboken, New Jersey, 2016.

10. K. Lai, A. C.; Nazaroff, W. W., Modeling Indoor Particle Deposition from Turbulent Flow onto Smooth Surfaces. J. Aerosol Sci 2000, 31 (4), 463-476.

11. Wang, C.; Collins, D. B.; Arata, C.; Goldstein, A. H.; Mattila, J. M.; Farmer, D. K.; Ampollini, L.; DeCarlo, P. F.; Novoselac, A.; Vance, M. E.; Nazaroff, W. W.; Abbatt, J. P. D., Surface reservoirs dominate dynamic gas-surface partitioning of many indoor air constituents. Sci. $A d v$. 2020, 6 (8), eaay8973. 